\title{
Cryobanking: the brave new world of biobanking and specimen cryopreservation
}

\author{
This article was published in the following Dove Press journal: \\ Journal of Biorepository Science for Applied Medicine \\ 10 June 2012 \\ Number of times this article has been viewed
}

\author{
Martin H Bluth \\ Department of Pathology, Wayne \\ State University School of Medicine, \\ Detroit Medical Center, Karmanos \\ Cancer Institute, Detroit, MI, USA
}

Correspondence: Martin H Bluth Department of Pathology, Wayne State University School of Medicine, Detroit Medical Center, Karmanos Cancer Institute, Detroit, MI 4820I, USA Email mbluth@med.wayne.edu
The layperson's depiction of people preservation often conjures up nefarious iterations of Jack Finney's 1954 novel, The Body Snatchers, or Ira Levin's thriller, The Boys from Brazil, where maintenance of human composition is employed for perpetuation of ill repute. Recent illustrations of animal preservation-reanimation gone wrong, such as the Jurassic Park films, further echoed such concerns. In contrast, during the 1980s, the advent of cloning morphed with cryopreservation to furnish jocularity in the form of many an Arnold Schwarzenegger film (Twins, Junior). The late 1980s and early 1990s also demonstrated a greater degree of reality-based cryopreservation, public acceptance, and clinical application in the form of cord blood-banking, stem cell transplantation, and in-situ fertilization technologies, thus positively affecting both the biobanking image and human health. ${ }^{1}$

So where are we now? In the last decade or so, tissue and fluid preservation, also known as biobanking, biorepository science, or cryopreservation - often referred to as cryobanking - has become mainstream and big business. According to research by the British Broadcasting Corporation, the global biobanking market in 2010 was over $\$ 140$ billion dollars, with a projected 30\% increase by the year 2015 towards fostering biobanking initiatives. ${ }^{2}$

The basic idea behind biobanking is straightforward: collect and store tissues obtained from patients with select disease and, in time, you will have access to thousands of specimens to perform the interrogation of choice. These can include but are not limited to: biomarker discovery, pre/post-drug monitoring, disease prognostication, population screening, and sex/race/ethnicity demographics. ${ }^{3}$ The stem cell explosion, where reports increasingly suggest that stem cells exist in almost any organ, with the added potentiality of being able to regrow any diseased or damaged organ, provides perfectly poised positioning for the cryobanking industry to regrow a new you from an earlier cellular version of your deep frozen self. Such strategies have been implemented into the animal-based food industry. ${ }^{4}$ The possibilities appear to be limited to the imagination.

But there are a few hard strops along the way: cost is a major issue. One needs to project the type of bank (disease-specific?), tissues collected (body fluids versus solid tissues and their tributaries), rate of collection, anticipated sample size, collection logic (transport), overhead, labor, time, heating and cooling, structural edification, equipment and maintenance costs, and real estate, among others, to determine what type of infrastructure is necessary. ${ }^{5}$ 
On the other end, identification of the user or client is critical when contemplating such a setup. Who is the customer? To this end there are varied lines of thought. Academic centers that set up their own biobanks can be focused towards maturing enough specimens in short order to submit program project grants, vie for competitive foundation and/or association awards, in addition to fostering their own research imperatives. Pharmaceutical companies may share some of these goals in addition to other commercial incentives. Industry may have a vested interest in biobanking selective big-ticket diseases, such as diabetes and cardiovascular disease, as a means to mature a more personalized pharmacopoeia for distinct patient populations and as such tailor both biomarker discovery and therapeutic interventions towards greater clinical efficiency. ${ }^{3}$ Both academia and industry may form partnerships that are mutually benefitting. ${ }^{6}$

Methodology also presents a concern of reasonable magnitude. Analytes often change over time. To this end, characteristics of specimens stored at $-80^{\circ} \mathrm{C}$ may differ from those stored at $-120^{\circ} \mathrm{C}$ or colder, ${ }^{7}$ over a 10 -year period. Will there be any form of analyte "leaching" over time that may impact laboratory results at a later date? Will protocols differ among biobank warehouses? Specimen processing and storage optimization should be assessed and standardized prior to embarking on any biobanking quest, with the understanding that there may be considerable unknowns along the way. The reason is that this is a relatively young science and time will tell what, if any, alterations of tissue and analyte modulation occur when specimens are subjected to different procedural and long-term deepfreeze storage algorithms.

It goes without saying that safety and respect of human subjects need to be maintained. Any self-respecting biobank will be tethered to an Institutional Review Board, which will provide guidance and facilitate its maturation, maintenance, and propagation. Patient or volunteer information, security, and/or deidentification will need to be dovetailed into any collection algorithm. Instituting some sort of patient/ volunteer-biobank partnerships may foster additional synergy in this regard. ${ }^{9}$ However, cryobanks will also need to incorporate a means of addressing look-backs into mining additional patient or volunteer personal information, as new developments may require such retrospectives 20 years after the specimen has been obtained. Institutional Review Boards would need to forecast such eventualities.

Biobanking of animal tissue may prove value-added when considering the number of different animal models of a disease available in the translational medicine marketplace. For example a communal "cryobank" of serum obtained from the numerous models of animal pancreatitis may conserve resources among investigators who seek biomarker discovery and share in the data. However, as in the world of drug development, there may be differences in the behavior of human versus animal tissue analytes in these respects as well, which may impact clinical application.

Another issue involves the ownership, intellectual property, and marketing of these banked samples. How long will the specimens be stored: 5, 10, 30 years, or longer? What happens if the mutually agreed upon exit strategy is not achieved? If one party walks away? Who maintains jurisdiction of the samples? Ideally, contracts and policies should provide some degree of boilerplate in this regard as a means to ward off future lawsuits. To this end, an ounce of prevention will likely prevent a pound of pain. ${ }^{10}$

In conclusion, this provocative and alluring world has hurdles to overcome, both known and unknown. To this end, the Journal of Biorepository Science for Applied Medicine serves to provide a forum to address, expand, and innovate on the thoughts presented above and those not yet formed. Whether one prefers aggressive involvement or to remain a spectator, the inculcation of biorepository science into mainstream medicine posits the magic of creativity, hope of longevity, and potentiality of true and lasting cures that we all hope for.

\section{Disclosure}

The author reports no conflicts of interest in this work.

\section{References}

1. Pullman D, Etchegary H, Gallagher K, et al. Personal privacy, public benefits, and biobanks: a conjoint analysis of policy priorities and public perceptions. Genet Med. 2012;14(2):229-235.

2. BBC Research. Biobanking: technologies and global markets. Report code BIO084A. Jun 2011. Available from: http://www.bccresearch.com/report/ biobanking-technologies-markets-bio084a.html. Accessed April 23, 2012.

3. Zatloukal K, Hainaut P. Human tissue biobanks as instruments for drug discovery and development: impact on personalized medicine. Biomark Med. 2010;4(6):895-903.

4. Leroy G, Danchin-Burge C, Verrier E. Impact of the use of cryobank samples in a selected cattle breed: a simulation study. Genet Sel Evol. 2011;43:36.

5. Vaught J, Rogers J, Carolin T, Compton C. Biobankonomics: developing a sustainable business model approach for the formation of a human tissue biobank. J Natl Cancer Inst Monogr. 2011;2011(42):24-31.

6. Lablans M, Bartholomäus S, Uckert F. Providing trust and interoperability to federate distributed biobanks. Stud Health Technol Inform. 2011;69: 644-648.

7. Santiago-Moreno J, Castaño C, Toledano-Díaz A, et al. Semen cryopreservation for the creation of a Spanish poultry breeds cryobank: optimization of freezing rate and equilibration time. Poult Sci. 2011; 90(9):2047-2053. 
8. Lewis LK, Robson M, Vecherkina Y, Ji C, Beall G. Interference with spectrophotometric analysis of nucleic acids and proteins by leaching of chemicals from plastic tubes. Biotechniques. 2010;48:297-302.

9. Saha K, Hurlbut JB. Research ethics: Treat donors as partners in biobank research. Nature. 2011;478:312-313.
10. Cambon-Thomsen A, Rial-Sebbag E, Knoppers BM. Trends in ethical and legal frameworks for the use of human biobanks. Eur Respir J. 2007;30:373-382.

\section{Publish your work in this journal}

Journal of Biorepository Science for Applied Medicine is an international, peer-reviewed, open access journal that focuses on new developments and advances in the emerging and evolving field of biorepository science. This includes biospecimen procurement, processing, preservation, and banking for application to applied medicine. The Journal invites submission of manuscripts which address these aspects in addition to systems logic, clinical throughput and ethical issues pertaining to application of biorepositorie and their affects on clinical medicine. The journal is characterized by the rapid reporting of reviews, original research, methodologies, technologies and analytics in this subject area. The manuscript management system is completely online and includes a very quick and fair peer-review system, which is all easy to use. Visit http://www.dovepress. com/testimonials.php to read real quotes from published authors.

Submit your manuscript here: http://www.dovepress.com/journal-of-biorepository-science-for-applied-medicine-journal 